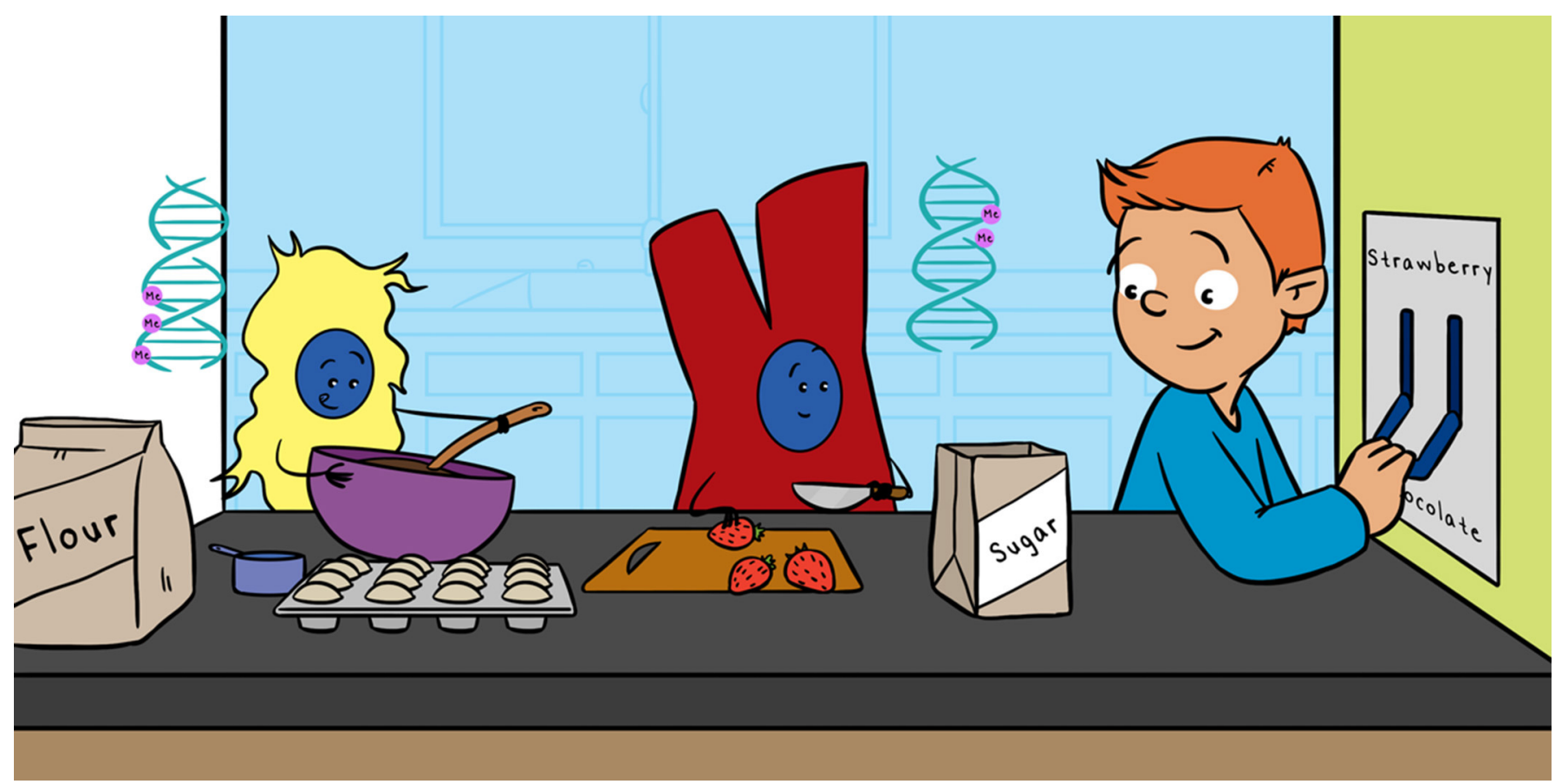

\title{
SWITCHING GENES ON AND OFF: HOW IT CAN SHAPE US
}

\section{Mandy Meijer $^{1 *}$, Jeanette Mostert ${ }^{1}$, Barbara Franke ${ }^{1,2}$ and Marieke Klein ${ }^{1,3}$}

${ }^{1}$ Department of Human Genetics, Donders Institute for Brain, Cognition and Behaviour, Radboud University Medical Center, Nijmegen, Netherlands

${ }^{2}$ Department of Psychiatry, Donders Institute for Brain, Cognition and Behaviour, Radboud University Medical Center, Nijmegen, Netherlands

${ }^{3}$ Department of Psychiatry, UMC Utrecht Brain Center, University Medical Center Utrecht, Utrecht, Netherlands

YOUNG REVIEWER:

EMILY

AGE: 11
The human body consists of more than 200 different types of cells, but all cells contain the same DNA code. How is it possible that the same code tells the various types of cells to be different? The information for life is not only coded in the DNA, but also on the DNA. Chemical attachments, which are called DNA methylation, can "turn off" parts of the DNA code that are not needed in a specific cell. DNA methylation can also be influenced by our surroundings. Sometimes, changes in DNA methylation might lead to diseases. Understanding how our surroundings can influence DNA methylation might also help us to better understand the mechanisms causing some diseases and hopefully get better at curing and preventing them. This article describes ADHD as one example. 
Figure 1

The body consists of many cell types, like heart cells and bone cells. Cells need different proteins to function the way they should. These proteins are coded by sections of the DNA called genes, and DNA methylation ("Me," purple circles) can turn off specific genes that are not needed. This ensures that only the necessary proteins are made in the cells, and that a heart cell develops differently than a bone cell.

DNA

Deoxyribonucleotide, a molecule that contains all the information a cell needs to know to stay alive and perform its functions. The DNA is subdivided into genes.

\section{GENE}

A section of DNA containing information on how to make a certain protein. Cells in the body need many proteins to function properly.

\section{DNA METHYLATION}

Addition of a chemical called a methyl group to DNA, resulting in a change to the DNA's structure that makes it more difficult to make proteins from the methylated gene.

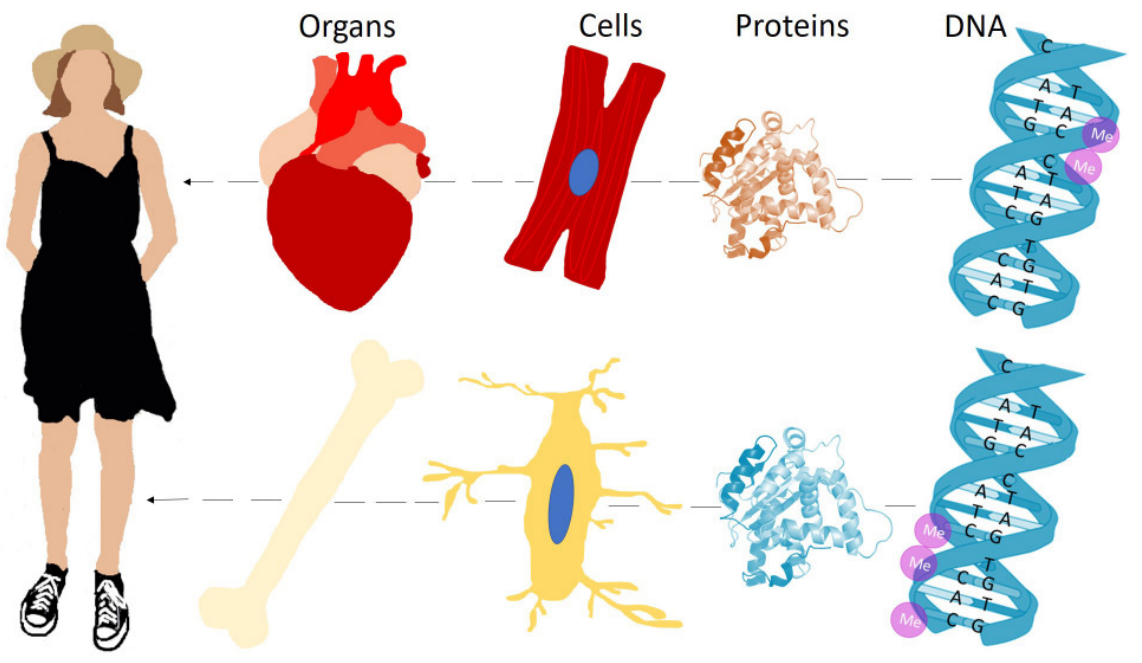

Figure 1

\section{SAME CODE, DIFFERENT CELLS}

Our bodies consist of different types of cells. Our heart cells look different from our bone cells, and they do different things. But all these cells contain exactly the same DNA code: the same long molecules, functioning as the "manual" of the cell. How, then, do all these cells look different from each other and have their own functions, when their manuals do not differ?

Our cells are like tiny factories that produce the proteins necessary for the cell to function. All cells might get the same manual, but they use different pages from the manual, called genes, to produce their specific proteins. For example, a heart cell needs to contribute to building the heart and help it pump blood through the body. But bone cells need to make strong and rigid bones. Heart cells and bone cells need different proteins, so they must use different genes.

\section{HOW DOES THE FACTORY KNOW WHAT IT NEEDS TO MAKE?}

The information for life is not only coded in the DNA, but also by chemicals added onto the DNA. One way the cell "turns off" certain genes is via a process called DNA methylation: a small chemical group called a methyl group is attached to the DNA. This alteration of the gene's structure makes the code less accessible, so the cell produces less of the protein that is coded for by that gene (Figure 1). You can compare this to the levers in the cake factory in Figure $2 \mathrm{~A}$, in which one lever has been switched to a different mode: make no more candles for the cakes! 
Figure 2

(A) When a gene is methylated, less protein is made from that gene. If the cake factory is the DNA, DNA methylation can be compared to a lever. When the lever of the candle-making machine is off, fewer candles (proteins) will be produced, resulting in cakes (bodies) without candles. (B) DNA methylation can be influenced by our surroundings. When strawberry season is over, the factory decides to make more chocolate cakes, so the speed of the chocolate-coating machine must be increased. The candles and the

chocolate-coating represent two different genes can be made into proteins in a cell.

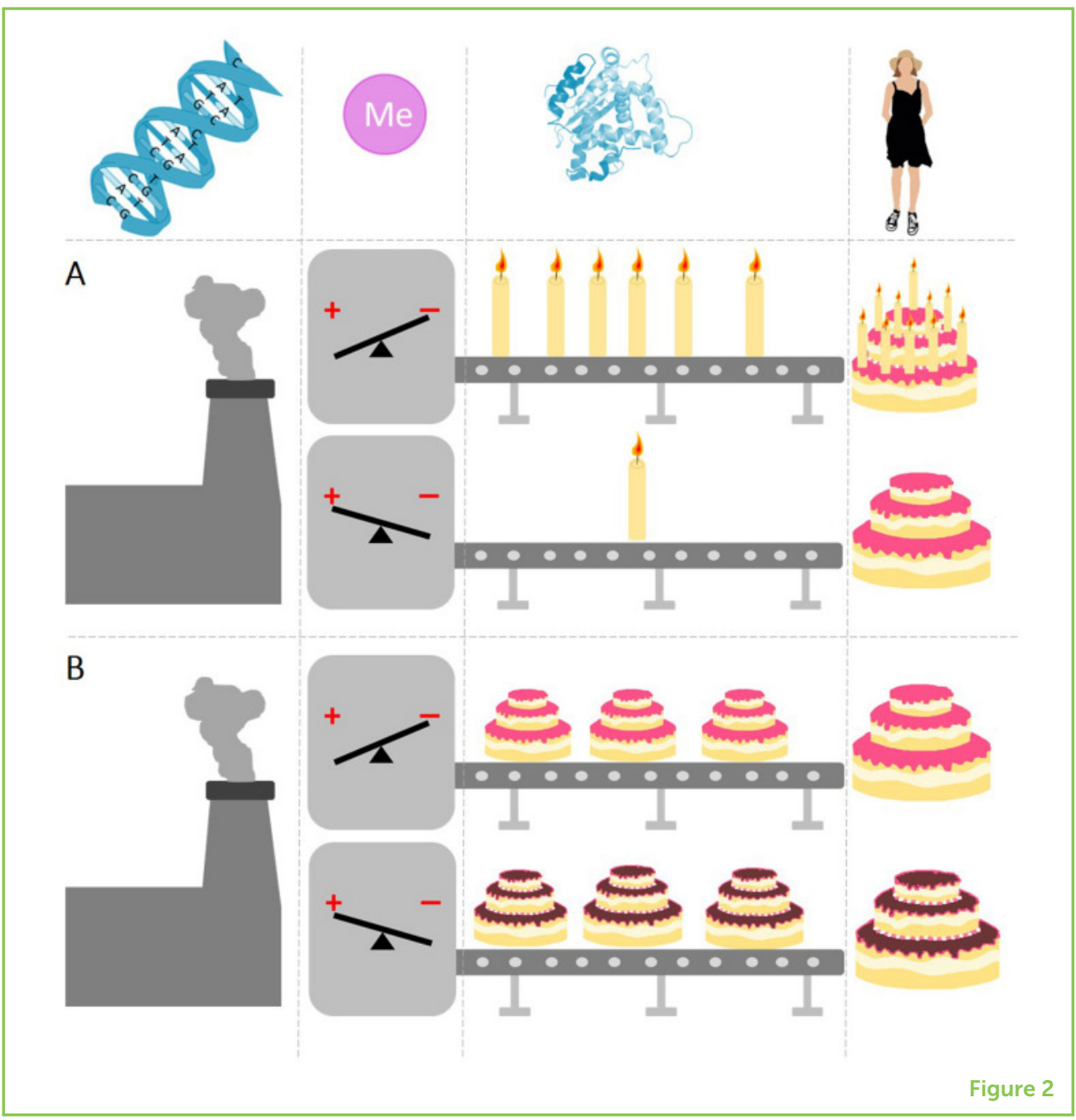

\section{SURROUNDINGS AFFECT DNA METHYLATION}

DNA methylation does not only determine whether a cell is going to be a heart cell or a bone cell. The amounts of proteins cells produce affect how the body functions and can also influence how we behave. Our surroundings, including our living environments and the people we interact with, can influence the methylation of the DNA and the production of certain proteins. This is very convenient, because sometimes we need to adapt to changing surroundings, for example, if we move to a new country with a different climate and different food. You could compare this to the cake factory example: citizens of the city in which our cake factory is situated love to eat strawberry-coated cakes, so the factory makes fewer chocolate-coated cakes. But when strawberry season is over, the factory decides to make more chocolate-coated cakes. It does so by switching the lever that controls the production of chocolate (Figure 2B). The lever can also control the speed of chocolate production-it can be set to the fastest speed possible, completely switched off, or be anywhere in between these two extremes. 


\section{WHICH SURROUNDINGS INFLUENCE DNA METHYLATION?}

Your surroundings include anything that influences your body from the outside. One example of the effect of surroundings on DNA methylation is smoking. Researchers have found that people who smoke have different DNA methylation across the whole DNA code than non-smokers do [1]. When a mother smokes during pregnancy, even the baby's DNA methylation will be altered by the mother's smoking, and many of these alterations last until at least the age of 7 years [2]. In another example of the effects of surroundings even before birth, if a mother experiences really high levels of stress during pregnancy, her child will show altered DNA methylation of stress-related genes [3]. These alterations in DNA methylation prepare the child for a harsh environment. However, such changes may also make the child more vulnerable to some diseases and disorders, like allergies or depression.

\section{ADHD}

Attention-deficit/ hyperactivity disorder a disorder that causes people to experience difficulties concentrating and/or hyperactivity and impulsivity.

\section{REMITTENT ADHD}

Some people have ADHD when they are kids, but during adulthood they do not show any symptoms any more.

\section{PERSISTENT ADHD}

Some people with ADHD show symptoms when they are kids. When they are adults they still have the disorder and show the symptoms.

\section{DNA METHYLATION AND ADHD?}

So far, we have described how DNA methylation can determine which proteins a cell produces, and therefore its function. We also described that DNA methylation can happen in response to a person's surroundings. As researchers, we are interested in DNA methylation and attention-deficit/hyperactivity disorder (ADHD). One in twenty kids experiences hyperactivity, impulsivity, and/or inattention, which are typical symptoms of ADHD. Some children with ADHD no longer show such problems when they are grown up. We call their type of ADHD remittent ADHD. However, over half of the children with ADHD still experience symptoms during adulthood. They have what we call persistent ADHD. It is important to know what the differences are between people who have remittent ADHD and those who have persistent ADHD. Understanding the differences might allow us to help people overcome ADHD, however, we do not yet understand what these differences are. So far, researchers have only looked at genes themselves to find the differences. We are now starting to investigate whether DNA methylation might be playing a role in ADHD.

\section{HOW DO WE STUDY DNA METHYLATION IN ADHD?}

We asked more than 50 12-year-old children with ADHD to come to our laboratory. Five and 9 years later, when the children were age 17 and 21, we invited them again and checked whether they still had ADHD [4]. In this way, we could determine whether their ADHD was remittent or persistent. At the third visit, we also drew blood from the participants. We isolated the DNA from the participants' blood, to see where each individual's DNA was methylated (Figure 3). Then we compared the DNA methylation of all participants with 
Figure 3

We asked 12-year-old children to come to our laboratory and we assessed whether they had ADHD. Five and 9 years later, when the children were 17 and 21 years old, they returned, and we assessed whether they still had ADHD. Those who no longer had ADHD at 21 were classified as remittent ADHD, and those who still had ADHD were classified as persistent ADHD. At age 21, we also drew blood from all participants, to study DNA methylation.

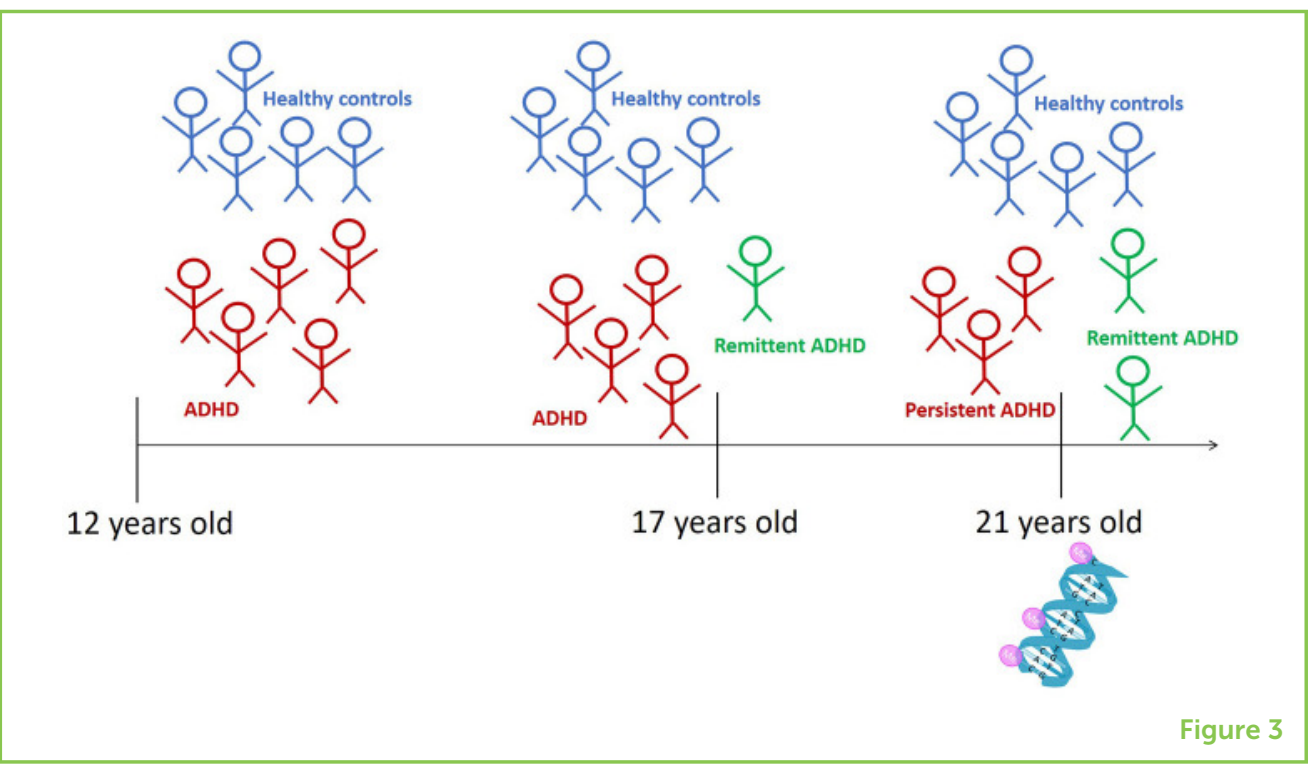

persistent ADHD to the DNA methylation of all participants with remittent ADHD.

We found more methylation on a specific gene in participants with persistent ADHD. We think that, as a result, people with persistent ADHD make less of a protein called APOB. APOB's job is to carry cholesterol throughout the body. Perhaps you have heard of cholesterol as a "bad" substance, found in some unhealthy foods. But cholesterol is also important for the development and maintenance of brain cells, so the body needs it in small amounts. We think that lower production of $\mathrm{APOB}$ and the resulting effects on cholesterol might help to explain why some individuals have persistent ADHD [5]. Importantly, if we had looked at the DNA code instead of at DNA methylation, we would not have found any differences in the APOB gene between the two groups of study participants.

Research like ours shows that DNA methylation is very important for the development and functioning of the body-ADHD is only one example. Our study helped us to unravel one piece of the puzzle of why some individuals have persistent ADHD and others do not. These are exciting times for researchers, because we are learning more and more about the role of DNA methylation in health and disease, and about aspects of our surroundings that influence DNA methylation. There is also still a lot to learn and discover about DNA methylation and hopefully what we learn will help us to improve the life of people with methylation-related disorders.

\section{ORIGINAL SOURCE ARTICLE}

Meijer, M., Klein, M., Hannon, E., van der Meer, D., Hartman, C., Oosterlaan, J., et al. 2020. Genome-wide DNA methylation 
patterns in persistent attention-deficit/hyperactivity disorder and in association with impulsive and callous traits. Front. Genet. 11:16. doi: 10.3389/fgene.2020.00016

\section{REFERENCES}

1. Zeilinger, S., Kuhnel, B., Klopp, N., Baurecht, H., Kleinschmidt, A., Gieger, C., et al. 2013. Tobacco smoking leads to extensive genome-wide changes in DNA methylation. PLOS ONE 8:e63812. doi: 10.1371/journal.pone.0063812

2. Joubert, B. R., Felix, J. F., Yousefi, P., Bakulski, K. M., Just, A. C., Breton, C., et al. 2016. DNA methylation in newborns and maternal smoking in pregnancy: genome-wide consortium meta-analysis. Am. J. Hum. Genet. 98:680-96. doi: 10.1016/j.ajhg.2016.02.019

3. Mitchell, C., Schneper, L. M., and Notterman, D. A. 2016. DNA methylation, early life environment, and health outcomes. Pediatr. Res. 79:212-9. doi: 10.1038/ pr.2015.193

4. von Rhein, D., Mennes, M., van Ewijk, H., Groenman, A. P., Zwiers, M. P., Oosterlaan, J., et al. 2015. The NeurolMAGE study: a prospective phenotypic, cognitive, genetic and MRI study in children with attention-deficit/hyperactivity disorder. Design and descriptives. Eur. Child Adolesc. Psychiatry 24:265-81. doi: 10.1007/s00787-014-0573-4

5. Meijer, M., Klein, M., Hannon, E., van der Meer, D., Hartman, C., Oosterlaan, J., et al. 2020. Genome-wide DNA methylation patterns in persistent attention-deficit/hyperactivity disorder and in association with impulsive and callous traits. Front. Genet. 11:16. doi: 10.3389/fgene.2020.00016

SUBMITTED: 02 April 2020; ACCEPTED: 06 April 2021; PUBLISHED ONLINE: 27 April 2021.

EDITED BY: Daniel W. Wesson, University of Florida, United States

CITATION: Meijer M, Mostert J, Franke B and Klein M (2021) Switching Genes On and Off: How It Can Shape Us. Front. Young Minds 9:548370. doi: 10.3389/frym. 2021.548370

CONFLICT OF INTEREST: BF received educational speaking fees from Medice.

The remaining authors declare that the research was conducted in the absence of any commercial or financial relationships that could be construed as a potential conflict of interest.

COPYRIGHT @ 2021 Meijer, Mostert, Franke and Klein. This is an open-access article distributed under the terms of the Creative Commons Attribution License (CC BY). The use, distribution or reproduction in other forums is permitted, provided the original author(s) and the copyright owner(s) are credited and that the original publication in this journal is cited, in accordance with accepted academic practice. No use, distribution or reproduction is permitted which does not comply with these terms. 


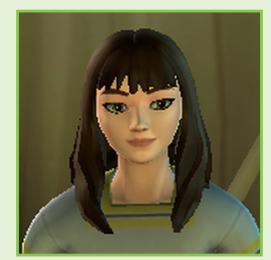

\section{YOUNG REVIEWER}

\section{EMILY, AGE: 11}

My name is Emily and I am an 11-year-old aspiring lawyer. I live in London, England and have recently started secondary school. My favorite subject is English literature. In my free time I enjoy playing Minecraft and reading Harry Potter.

\section{AUTHORS}
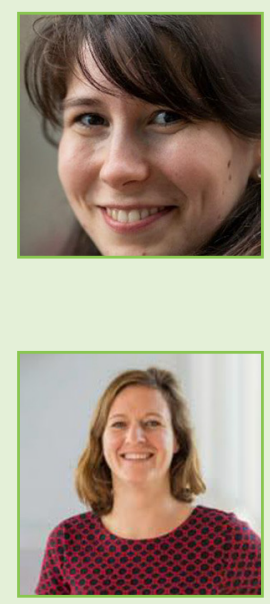

\section{MANDY MEIJER}

I am a young researcher intrigued by how everything in the body interacts with each other and makes us who we are. My goal is to better understand aggressive and impulsive behaviors by looking at the interplay between the environment and the DNA. When I am not busy with my research, I like to sing with my choir, dance, or have walks in nature. *mandy.meijeraradboudumc.nl

\section{JEANETTE MOSTERT}

I first studied how adults with ADHD have different connections between their brain areas, and how this can explain their ADHD symptoms. Now, I am using my knowledge about genes, brains, and ADHD to explain our research to other people: children, students, people with ADHD, and doctors. I also help researchers to become better science communicators. In my free time, I play the cello, and I like outdoor activities like hiking, running, and cycling.

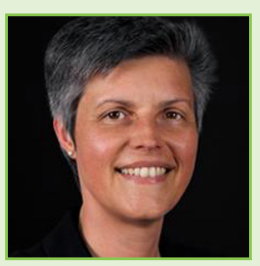

\section{BARBARA FRANKE}

I am a professor of molecular psychiatry and interested in understanding how differences in the genetic make-up of people can contribute to psychiatric disorders. It is my goal to use this information to improve the diagnosis and treatment of such disorders. To do this, I like to collaborate with researchers across the globe, because sharing knowledge is the best way to understand complex things.

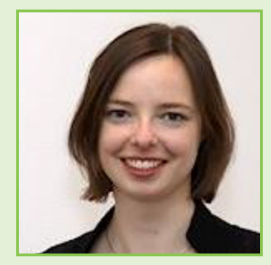

\section{MARIEKE KLEIN}

As a researcher, my goal is to identify variants in the DNA code that influence human behavior and psychiatric disorders. I also want to know how these genetic variants influence brain development. When I am not teaching or researching, I can be found spending time with family and friends-ideally while hiking, biking, or skiing. 